\title{
PERJANJIAN BANTUAN TIMBAL BALIK DALAM MASALAH PIDANA ANTARA REPUBLIK INDONESIA DAN REPUBLIK ISLAM IRAN
}

\author{
(Reciprocal Judiciary Assistance Agreement in The Criminal Matters Between The \\ Republic of Indonesia and The Islamic Republic of Iran)
}

\author{
Firdaus \\ Pusat Penelitian dan Pengembangan Hak Asasi Manusia Badan \\ Penelitian dan Pengembangan Hukum dan Hak Asasi Manusia \\ Kementerian Hukum dan Hak Asasi Manusia R.I. \\ Jl. H.R. Rasuna Said Kav. 4-5, Kuningan Jakarta Selatan 12940 \\ Email: firdaus_ham@yahoo.co.id: firdausamir66@gmail.com
}

Tulisan Diterima: 30-08-2017; Direvisi: 20-10-2017; Disetujui Diterbitkan: 21-11-2017

\begin{abstract}
The development of science and technology, in particular the transportation, communications, and information has eliminated the boundaries between one country and another rendering the movement of people or goods from one country to another easier and quicker. This development has created some impacts to the crimes and their increasingly sophisticated operations, consequently the mitigation of the same would require cooperation between the countries. One of the efforts in overcoming the issue is by establishing good bilateral relations with another country of similar interests in the form of reciprocal juridical assistance on criminal matters. This research uses the normative juridical and juridical empirical approaches and aimed to answer the urgency of reciprocal juridical assistance agreement and ratification thereof in criminal matters, and to identify substantial provisions of the reciprocal juridical assistance agreement in the criminal matters. This paper focuses on the urgency to support the ratification of the reciprocal juridical assistance agreement of criminal matters in relation to narcotics and acts of terrorism as well as the substantial provisions of the reciprocal juridical assistance agreement in criminal matters. This paper recommends immediate ratification of the agreement subject to the applicable national laws, and strengthening some agencies to support the performance of the reciprocal juridical assistance agreement in criminal matters between the Republic of Indonesia and the Islamic Republic of Iran.
\end{abstract}

Keywords: Agreement, Assistance, Reciprocity, Criminal

ABSTRAK

Perkembangan ilmu pengetahuan dan teknologi terutama perkembangan transportasi, komunikasi, dan informasi mengakibatkan satu negara dengan negara lain seakan-akan tanpa batas sehingga perpindahan orang atau barang dari satu negara ke negara lain dilakukan dengan mudah dan cepat. Perkembangan ini menimbulkan dampak hukum pidana terhadap kejahatan dan modus operandinya semakin canggih sehingga penanggulangannya diperlukan kerjasama antara negara yang satu dengan negara lainnya. Upaya mengatasi permasalahan tersebut dengan menjalin hubungan bilateral yang baik dengan negara-negara yang memiliki kepentingan yang sama, salah satunya dengan melakukan kerjasama bantuan timbal balik dan masalah pidana. Metode penelitian ini menggunakan pendekatan yuridis normatif dan yuridis empiris, tulisan ini untuk menjawab apa urgensi yang dilakukan ratifikasi dan perjanjian bantuan timbal balik dalam masalah pidana, dan untuk melihat apa substansi yang diatur dalam perjanjian bantuan timbal balik dalam masalah pidana. Tulisan difokuskan pada urgensi untuk mendukung pelaksanaan pengesahan bantuan timbal balik masalah pidana terkait pemberantasan narkotika dan tindakan terorisme dan substansi yang diatur dalam perjanjian bantuan timbal balik dalam masalah pidana. Rekomendasi dari tulisan ini, dapat segera meratifikasi perjanjian dengan ketentuan hukum nasional yang berlaku, dan penguatan beberapa lembaga untuk mendukung pelaksanaan bantuan timbal balik hukum pidana antara Republik Indonesia dan Republik Islam Iran.

Kata Kunci: Perjanjian, Bantuan, Timbal Balik, Pidana 


\section{PENDAHULUAN}

Tujuan Negara Republik Indonesia sebagaimana tercantum dalam Pembukaan Undang-Undang Dasar Negara Republik Indonesia Tahun 1945, yaitu melindungi segenap bangsa Indonesia dan seluruh tumpah darah Indonesia, memajukan kesejahteraan umum dan mencerdaskan kehidupan bangsa dan ikut melaksanakan ketertiban dunia yang berdasarkan perdamaian abadi, dan keadilan sosial, Pemerintah Republik Indonesia sebagai bagian dari masyarakat internasional melakukan hubungan kerja sama internasional yang diwujudkan dalam perjanjian internasional.

Oleh karena itu, perkembangan ilmu pengetahuan dan teknologi terutama perkembangan transportasi, komunikasi, dan informasi mengakibatkan satu negara dengan negara lain seakan-akan tanpa batas sehingga perpindahan orang atau barang dari satu negara ke negara lain dilakukan dengan mudah dan cepat. Hal ini mengakibatkan pula perkembangan kejahatan dan modus operandinya semakin canggih sehingga penanggulangannya diperlukan kerja sama antara negara yang satu dengan negara yang lain (Penjelasan Undang-Undang Nomor 1Tahun 2006 tentang Bantuan Timbal Balik Dalam Masalah Pidana). Namun saat ini telah banyak jenis kerja sama hukum yang dikembangkan dan dilakukan oleh negaranegara, yang salah satunya adalah kerja sama Bantuan Timbal Balik dalam Masalah Pidana (Mutual Legal Assistance in Criminal Matters atau disingkat MLA).

Perkembangan hubungan diplomatik antara Republik Indonesia dan Republik Islam Iran, selain meningkatkan hubungan persahabatan dan hubungan dagang, juga meningkatnya ilmu pengetahuan dan teknologi khususnya di bidang transportasi, komunikasi, dan informasi. Selain hubungan tersebut mempunyai dampak positif tetapi tidak menutup kemungkinan adanya dampak negatip, yaitu timbulnya tindak pidana yang tidak lagi mengenal batas yurisdiksi suatu Negara, sehingga penanggulangan dan pemberantasannya memerlukan kerja sama antar negara yang efektif bersifat bilateral.

Saat ini terdapat sekitar 100 (seratus) Warga Negara Iran yang berhadapan dengan permasalahan hukum di Indonesia, dimana sebagian besar merupakan kasus narkotika. Terkait isu perlindungan hak asasi manusia, pihak Republik Islam Iran berpandangan bahwa terdapat perbedaan mendasar antara pengertian perlindungan HAM berdasarkan ajaran agama Islam dengan pengertian barat sebagaimana tertuang dalam Universal Declaration of Human Rights, International Covenant on Civil and Political Rights. Lebih lanjut, pihak Republik Islam Iran menyampaikan bahwa sebagai negara dengan penduduk mayoritas Islam terbesar di dunia, Republik Indonesia dan Republik Islam Iran perlu mempererat kerjasama tersebut dapat tertuang dalam MoU kerjasama kedua negara (Kementerian Luar Negeri RI, 24-25 Februari 2016). Sedangkan untuk jumlah wisatawan Republik Islam Iran yang berwisata ke luar negeri berjumlah 10 (sepuluh) juta orang per tahun. Namun demikian, jumlah kunjungan warga negara Republik Islam Iran ke Indonesia. Berdasarkan data Direktorat Jenderal Imigrasi, Kementerian Hukum dan Hak Asasi Manusia baru mencapai angka 9 (sembilan) ribu orang dalam periode Januari sampai dengan November 2016 (Kementerian Luar Negeri RI, 4-6 Desember 2016). Sedangkan menurut Data Direktorat Jenderal Pemasyarakatan, Jumlah Narapidana dan Tahanan Warga Negara Iran berdasarkan jenis kejahatan berjumlah 91 (sembilan puluh satu) warga Negara Iran yang bermasalah dengan hukum.

Oleh karena itu, penandatanganan nota kesepahaman dilakukan negara Republik Indonesia usai pertemuan Presiden Jokowi dengan Presiden Iran Hassan Rouhani di Istana Sa'dabad, Teheran. Ada 4 (empat) nota kesepakatan yang ditandatangani yakni Mutual Legal Assistance (MLA), ekstradisi, kelistrikan dan energi, serta investasi (https://news. detik. com/berita/d-3372675/indonesia-iran-sepakatsaling-bantu-dibidang-hukum, diunduh pada tanggal 5 April 2017). Perkembangan hubungan diplomatik antara Republik Indonesia dan Republik Islam Iran selain meningkatkan hubungan persahabatan dan hubungan dagang, juga meningkatnya ilmu pengetahuan dan teknologi khususnya di bidang transportasi, komunikasi, dan informasi. Selain hubungan tersebut mempunyai dampak positif tetapi tidak menutup kemungkinan adanya dampak negatip, yaitu timbulnya tindak pidana yang tidak lagi mengenal batas yurisdiksi suatu Negara, sehingga penanggulangan dan pemberantasannya memerlukan kerja sama antar negara yang efektif bersifat bilateral (Kementerian Luar Negeri RI, Direktorat 
Jenderal dan Konsuler: Laporan Perundingan Perjanjian Ekstradisi dan Perjanjian MLA, 24-25 Februari 2016).

Untuk perjanjian MLA, Indonesia telah memiliki perjanjian MLA bilateral dengan Australia, Korea Selatan, Hongkong, RRT, Vietnam, dan UEA.Lebih lanjut, bahwa perjanjianperjanjian MLA yang telah diratifikasi Indonesia tersebut menunjukkan komitmen kuat Republik Indonesia untuk mecegah dan memberantas kejahatan lintas negara (Kementerian Luar Negeri RI, Direktorat Jenderal dan Konsuler: Laporan Perundingan Perjanjian Ekstradisi dan Perjanjian MLA ,24-25 Februari 2016).

Dalam mempersiapkan penanggulangan dan pemberantasan timbulnya tindak pidana memerlukan kerja sama antar negara yang efektif bersifat bilateral, dalam hal ini dalam bentuk "bantuan timbal balik dalam masalah pidana" kemudian disebut bantuan yang merupakan permintaan bantuan berkenaan dengan penyidikan, penuntutan, dan pemeriksaan di sidang pengadilan sesuai dengan ketentuan peraturan perundang- undangan Negara Republik Indonesia dan Negara Republik Islam Iran.

Indonesia pada tahun 2006 telah mempunyai Undang-Undang Nomor 1 Tahun 2006 tentang Bantuan Timbal Balik Dalam Masalah Pidana (Mutual Legal Assistance). Undang-Undang ini telah mengatur mengenai permintaan bantuan timbal balik dalam masalah pidana baik dari Pemerintah Republik Indonesia kepada negara lain maupun dari negara lain kepada Pemerintah Republik Indonesia, antara lain: persyaratan pengajuan permintaan bantuan, bantuan untuk mencari atau untuk mengidentifikasi orang, bantuan untuk mendapatkan alat bukti, bantuan untuk mengupayakan kehadiran orang, pemblokiran, penyitaan hingga bantuan pemulangan aset hasil tindak pidana. Undang-undang ini juga merupakan dasar bagi Pemerintah Indonesia dalam menegosiasikan permbentukan perjanjian MLA dengan negara lain.

Tulisan ini hendak mengupas dua hal penting, yaitu, pertama apa urgensi dilakukannya ratifikasi perjanjian Bantuan Timbal Balik dalam Masalah Pidana Antara Republik Indonesia dan Republik Islam Iran, kedua, apa substansi yang diatur dalam Perjanjian Bantuan Timbal Balik dalam Masalah Pidana Antara Republik Indonesia dan Republik Islam Iran.

\section{METODE PENELITIAN}

Metode penelitian ini menggunakan pendekatan yuridis normatif dan yuridis empiris. Pendekatan yuridis normatif adalah pendekatan masalah dengan melihat, menelaah dan menginterpretasikan hal-hal yang bersifat teoritis yang menyangkut asas-asas hukum yang berupa konsepsi, peraturan perundang-undangan, pandangan, doktrin hukum dan sistem hukum yang berkaitan. Jenis pendekatan ini menekankan pada diperolehnya keterangan berupa naskah hukum yang berkaitan dengan objek yang diteliti. Sedangkan pendekatan yuridis empiris yaitu cara prosedur yang dipergunakan untuk memecahkan masalah penelitian dengan meneliti data sekunder terlebih dahulu untuk kemudian dilanjutkan dengan mengadakan penelitian terhadap data primer di lapangan (Soekanto dan Sri Mamudji. 2006: 52)

Penggunaan dari metode yuridis empiris dalam penelitian ini, yaitu dari hasil pengumpulan dan penemuan data serta informasi melalui studi lapangan melalui beberapa metode pengumpulan data primer: yaitu data yang langsung diperoleh dari Competent Authority di tingkat pusat yaitu:

(i) Kementerian Hukum dan HAM Republik Indonesia c.q Otoritas Pusat dan Hukum Internasional, Direktorat Jenderal Administrasi Hukum Umum (Ditjen AHU); (ii) Kementerian Luar Negeri Republik Indonesia c.q Direktorat Jenderal Hukum dan Perjanjian Internasional; (iii) Kejaksaan Agung Republik Indonesia c.q Biro Hukum dan Hubungan Luar Negeri;dan (iv) Kepolisian Negara Republik Indonesia c.q Devisi Hubungan Internasional, yaitu lembaga yang berwenang untuk melakukan pengajuan dan penanganan permintaan bantuan timbal balik dalam masalah pidana, maupun data sekunder yaitu data yang sudah tersedia sehingga tinggal mencari dan mengumpulkannya, seperti misalnya data-data yang ada di Ditjen AHU, Polri, Kejaksaan Agung, Kemlu, maupun di internet.

Secara oprasional penelitian yuridis normatif dilakukan dengan penelitian kepustakaan. Sedangkan pendekatan secara yuridis empiris dilakukan dengan mewawancara beberapa narasumber yang berkompeten dan berhubungan dengan penulisan ini, untuk mendapatkan data secara oprasional penelitian empiris dilakukan dengan penelitian lapangan. 


\section{PEMBAHASAN}

\section{A. Sejarah Bantuan Hukum Timbal Balik Dalam Masalah Pidana}

Bantuan hukum timbal balik dalam masalah pidana (Mutual Legal Assistancein Criminal Matters) adalah salah satu bentuk kerjasama internasional selain Ekstradisi, Perjanjian Pemindahan Narapidana (Transfer of Sentenced Person).

Pada awalnya MLA berawal dari kerjasama antar negara dalam suatu proses saling membantu dalam penyidikan masalah pidana yang bermula dari kerjasama antar kepolisian maupun "letters rogatory"(Cyrer, Hakan Friman, 2010:102) yang merupakan suatu sistem permintaan bantuan yang didasarkan pada sikap saling menghargai dalam rangka mendapatkan alat bukti, yang selanjutnya berkembang menjadi suatu bentuk perjanjian dan berbagai bentuk bantuan lainnya (International Assistance, http://www. ppsc-sppc.gc.ca/eng/fps-sfp/fpd/ch43.html, diunduh pada 20 Maret 2017).

Letters rogatory merupakan suatu surat yang diterbitkan oleh pengadilan suatu negara untuk memperoleh bantuan dari pengadilan negara lain. Adanya Letters rogatory dikarenakan berdasarkan prinsip kedaulatan, pengadilan suatu negara dilarang untuk melaksanakan kekuasaan diluar wilayah jurisdiksinya termasuk juga untuk mendapatkan alat bukti yang terdapat di luar negeri untuk kepentingan persidangan, sehingga suatu negara harus mengajukan permintaan terlebih dahulu kepada negara yang diminta apabila ingin mendapatkan alat bukti tersebut.

Berdasarkan United Nations Convention Againts Transnational Organized Crimes (UNTOC)/Palermo Convention 2000, bantuan hukum pidana timbal balik atau Mutual Legal Assistance in Criminal Matters (MLA) ini meliputi perolehan barang bukti dan pernyataan, menyediakan bantuan dokumen-dokumen hukum, melaksanakan penelusuran dan penyitaan, melaksanakan pemeriksaan objek dan lokasi, menyediakan informasi, bukti, penilaian ahli, dokumen dan arsip-arsip, mengidentifikasi atau penelusuran proses kejahatan, harta benda, atau peralatan-peralatan yang digunakan untuk kepentingan pembuktian dan perampasan untuk kepentingan penyitaan (Pasal 13,
UNTOC), memfasilitasi kehadiran saksi-saksi dan berbagai bentuk bantuan lainnya yang tidak dilarang oleh hukum nasional. Meskipun begitu bantuan yang diberikan oleh suatu negara tidak harus terbatas pada yang disebutkan di atas, bantuan lainnya juga dapat diberikan sepanjang tidak bertentangan dengan hukum nasional suatu negara. (Jhon E Harris, International Cooperation in Fighting Transnational Organized Crime $: 114^{\text {th }}$ International Special Emphasis on Mutual Legal Assistance and Extradition, Training Course Visiting Experts Papers, 139)

Berkembangnya kejahatan-kejahatan yang berkarakteristik transnational maupun internasional seperti kelompok kejahatan terorganisir, narkotika, tindak pidana perdagangan orang, korupsi, tindak pidana pencucian uang membutuhkan suatu mekanisme bantuan dan kerjasama antara negara.

Bantuan hukum pidana timbal balik atau mutual legal assistance in criminal matters (MLA) adalah suatu bentuk kerjasama hukum dalam rangka penegakan hukum pidana khususnya terhadap tindak pidana yang memiliki unsur transnasional atau internasional. UNTOC pada Pasal 18 menyatakan secara tegas untuk mendorong bentuk kerjasama bantuan timbal balik dalam mengatasi tindak pidana yang menjadi ruang lingkup dalam TOC.

Adapun tujuan dibentuknya Bantuan Timbal Balik dalam Masalah Pidana adalah (BPHN, 2010:7):

1. Memenuhi kebutuhan dalam negeri

Hal ini ditujukan untuk membantu penegakan hukum di Indonesia dalam mengejar aset tersangka di luar negeri dan mengatasi kejahatan transnasional yang cenderung meningkat.

2. Memenuhi kebutuhan internasional

Merupakan amanat dari berbagai Konvensi Internasional antara lain UNTOC, UNCAC (United Nations Covention Againts Corruption) maupun rekomendasi dari FATF (The Financial Action Task Force) agar pembangunan Anti Money Laundering Regime di Indonesia dilengkapi dasar hukum yang kuat di bidang MLA in Criminal Matters.

Proses pengajuan MLA harus tetap menghargai, menghormati dan menjunjung tinggi kedaulatan negara lain yang terkait dengan 
prinsip kepastian, kerahasiaan, keterbukaan, kejahatan ganda, penistaan, hak asasi manusia, proporsionalitas dan resiprositas (Toolkit to Combat Trafficking in Persons, 2018: 148).

MLA adalah suatu bentuk perjanjian yang mengacu pada bantuan hukum yang dilakukan oleh suatu negara kepada negara dalam hal penyidikan, penuntutan atau penjatuhan suatu tindak pidana (Chapter 14: Mutual Legal Assistance and Extradition dalam www.usip.org/files/MC2/MC221-Ch14.pdf diunduh pada 22 Mei 2016). MLA seperti halnya ekstradisi dapat dilakukan baik secara formal melalui perjanjian maupun informal yang dilandaskan pada prinsip resiprositas. UU No 1 tahun 2006 (Penjelasan UU No 1 tahun 2006 tentang Bantuan Timbal Balik dalam Masalah Pidana menyatakan dengan tegas bahwa MLA dapat dilakukan berdasarkan suatu perjanjian dan jika belum ada perjanjian maka bantuan dapat dilakukan atas dasar hubungan baik. MLA saat ini mengalami perkembangan yang cukup signifikan antara lain dapat dilihat dengan adanya perjanjian-perjanjian MLA yang dilakukan secara bilateral, regional maupun subregional. Perjanjian tersebut antara lain, the Arab League Convention on Mutual Assistance in Criminal Matters, the Inter American Convention on Mutual Assistance in Criminal Matters (1992), ASEAN Treaty on Mutual Legal Assistance in Criminal Matters (2004), Scheme (The Harare Scheme) relating to Mutual Assistance in Criminal Matters within the Commonwealth (1986), The European Convention on Mutual Assistance in Criminal Matters (1959), European Convention on The Proceedings in Criminal Matters (1972), Nordic States Scheme (1962). Perjanjian tersebut di atas menunjukkan bahwa hampir semua benua termasuk Australia (The Mutual Assistance in Criminal Matters Act 1987) memiliki perjanjian MLA dan perjanjian ini telah berawal dari benua Eropa pada tahun 1959.

Prosedur MLA sendiri memiliki perbedaan antara yang dijalankan dalam negara-negara yang menganut Civil Law System dan negara-negara yang menganut Common Law System, meskipun begitu perbedaan ini tidak begitu penting dan pada umumnya perjanjian MLA sejalan dengan perjanjian ekstradisi. Penerapan MLA tidak harus didasarkan sepenuhnya pada perjanjian khusus MLA yang dilakukan secara bilateral, regional maupun subregional, Pasal 18 paragraf $9-29$ UNTOC memberikan peluang bahwa pada saat suatu negara tidak memiliki perjanjian MLA, MLA tetap dapat dilakukan bilamana negara tersebut merupakan negara pihak pada UNTOC sehingga dengan kata lain Pasal 18 Paragraf 9 - 29 UNTOC dapat dikatakan sebagai perjanjian MLA dalam skala yang kecil (Toolkit to Combat Trafficking in Persons, 2008:145).

Sebab itu pula harus ditarik garis pembeda antara penegakan kewajiban internasional dari perjanjian Republik Indonesia dan Republik Islam Iranuntuk menghormati dan menegakkan norma-norma hak asasi manusia sebagaimana muncul dalam perjanjian-perjanjian internasional atau sumber hukum internasional lainnya dengan persoalan penegakan hukum pidana trans/ internasional yang pada dasarnya juga melanggar atau meniadakan hak asasi orang lain.

Dalam lingkup hukum pidana trans/ internasional fokusnya bukan pada tanggungjawab negara untuk mengembangkan hukum nasional yang melindungi, menghormati hak asasi warga melainkan pada pengembangan ketentuan pidana yang disepakati bersama dan tanggungjawab penegakannya melalui sistem peradilan pidana pada perjanjian Republik Indonesia dan Republik Islam Iran yang bersepakat.

\section{B. Hak dan Kewajiban Negara dalam MLA \\ UN Model Treaty tentang MLA 1990} menyatakan bahwa MLA bukanlah: (i) Penangkapan atau penahanan seseorang dengan tujuan ekstradisi. (ii) Pemindahan narapidana (transfered of sentenced person). (iii) Pemindahan proses acara pidana.MLA merupakan instrumen penegakan hukum pidana (transnasional) yang penting dimana hal ini ditunjukkan dengan adanya The United Nations Model Law on Mutual Assistance in Criminal Matters berdasarkan Resolusi Majelis Umum PBB 53/112, 9 Desember 1998 yang merupakan suatu panduan yang dapat digunakan oleh negara-negara dalam menerapkan MLA. Untuk melaksanakan suatu MLA ada beberapa panduan yang merupakan aturan yang dapat digunakan untuk memperlancar terjadinya suatu MLA.

International Association of Prosecutor (International Association of Prosecutor adalah suatu asosiasi Penuntut Umum yang didirikan pada Juni 1995 di Kantor PBB di Wina Austria) memberikan suatu panduan bagi Penuntut Umum dalam rangka mengajukan suatu MLA yang terdiri 
dari tiga aturan dasar yaitu: (i) Isi dari permintaan MLA harus lengkap dan detil. Unsur kerahasiaan tidak harus selalu ada dalam setiap permintaan akan tetapi jika diminta unsur ini harus dinyatakan secara jelas di halaman muka dokumen. (ii) Permohonan bantuan kepada negara peminta hanya dimungkinkan ketika hukum negara peminta dimungkinkan dan hanya jika hasil permintaan tersebut merupakan bukti tambahan yang dianggap bernilai dalam proses penuntutan. Permohonan bantuan ini harus tetap memperhatikan prinsipprinsip dasar dalam kerjasama antar negara yaitu prinsip kepastian, kerahasiaan, penulusuran, kejahatan ganda, penistaan, hak asasi manusia, keseimbangan dan timbal balik. (iii) Pastikan kembali isi permintaan, pastikan bahwa semua hal-hal yang dibutuhkan secara jelas disampaikan disertai dengan semua lampiran yang dibutuhkan.

Kerjasama penegakan hukum melalui MLA tidak selalu dapat berjalan dengan baik, permohonan bantuan ini terdapat kemungkinan untuk ditolak oleh negara yang diminta. Penolakan ini didasarkan atas beberapa hal antara lain: (i) Apabila negara yang diminta dianggap permohonan bantuan tersebut ditujukan terhadap kejahatan yang dianggap sebagai kejahatan politik menurut negara yang diminta. (ii) Negara peminta menerapkan sanksi pidana mati. (iii) Kasus yang dijadikan dasar untuk meminta MLA dianggap kurang memadai (Refusalof Mutual Legal Assistanceor Extradition,http://www.unafei.or. jpenglish/pdf/PDFrms/no57/ 57-16.pdf, diunduh pada 1 Maret 2017).

Jika didasarkan pada UU No 1 tahun 2006 tentang MLA, penolakan diberikannya bantuan timbal balik didasarkan kepada: (i) tindak pidana atas orang tersebut dianggap sebagai tindak pidana politik, tindak pidana berdasarkan hukum militer, atau orang tersebut telah dibebaskan atau diberi grasi, atau orang tersebut melakukan tindak pidana yang jika dilakukan di Indonesia tidak dapat dituntut. (ii) berkaitan untuk menuntut atau mengadili orang, apabila dengan alasan suku, jenis kelamin, agama, kewarganegaraan atau pandangan politik atau akan merugikan kedaulatan, keamanan, kepentingan dan hukum nasional. (iii) apabila berkaitan dengan negara asing, apabila negara asing itu tidak memberikan jaminan bahwa bantuan itu dapat digunakan untuk penanganan perkara yang diminta, dan jaminan atas pengembalian barang bukti.(iv) tindak pidana tersebut jika dilakukan di luar wilayah Indonesia, bukan merupakan tindak pidana. (v) tindak pidana yang dilakukan oleh orang tersebut diancam dengan pidana mati (vi) akan merugikan suatu penyidikan, penuntutan, pemeriksaan di sidang pengadilan di Indonesia yang membahayakan keselamatan orang, atau membebani kekayaan negara (Sunarso, 2009:151).

Selain dasar penolakan yang tersebut di atas terdapat alasan-alasan lain yang dapat dijadikan dasar oleh suatu negara untuk menolak suatu permohonan MLA adalah adanya suatu ketidak percayaan antar negara, ketidak percayaan terhadap suatu sistem hukum selain permasalahan hak asasi manusia, alasan politis, masalah kedaulatan negara, kebudayaan, penegakan prinsip keadilan dalam suatu negara.

Berdasarkan UN Model Treaty on MLA terdapat berbagai kewajiban yang harus dipenuhi oleh suatu negara. Kewajiban tersebut antara lain:

1. Negara peminta wajib menjaga dan mengembalikan segala barang dan dokumen yang dimintakan serta dikembalikan kepada negara diminta, kecuali negara diminta menentukan lain (Pasal 7).

2. Negara diminta (requested state) memiliki kewajiban untuk memenuhi permintaan penelusuran, penetapan lokasi aset yang disembunyikan, melakukan penyidikan transaksi keuangan dari pemilik asset dimaksud, dan melakukan upaya untuk memperoleh informasi atau bukti untuk "mengamankan", aset tersebut (Optional Protocol UN Model Treaty on Mutual Assistance in Criminal Matters, 14 Desember 1990).

3. Negara diminta memperbolehkan putusan dinegara peminta dapat dilaksanakan di negara diminta untuk membekukan dan menyita aset hasil kejahatan yang dimaksud.

4. Tidak menolak permohonan MLA yang didasarkan hanya atas kerahasiaan bank.

Kewajiban negara dalam MLA juga dimintakan secara spesifik dalam rekomendasi yang disampaikan oleh Financial Action Task Force (FATF), yaitu:

1. Menjamin terlaksananya bantuan timbal balik masalah pidana untuk kepentingan penyidikan, penuntutan maupun pemeriksaan terkait dengan masalah tindak pidana pencucian uang dan pendanaan terorisme; 
2. Secara khusus negara tidak diperkenankan menetapkan pembatasan, persyaratan dan pencantuman alasan yang tidak berdasar pada ketentuan mengenai MLA;

3. Menjamin agar permintaan MLA dilakukan secara efektif;

4. Tidak diperkenankan menolak MLA (dari negara lain) karena alasan terkait masalah fiskal maupun ketentuan rahasia bank;

5. Menjamin bahwa central authority memiliki kewenangan untuk memproses permintaan MLA dari negara lain, termasuk dalam membantu memenuhi permintaan yang disampaikan oleh penegak hukum negara lain kepada counterpart di dalam negeri (Yunus Hussein, 2005:262).

\section{Urgensi Perjanjian Bantuan Timbal Balik dalam Masalah Pidana Terkait Tindak Pidana Antar Negara}

Urgensi perjanjian ini, ada solusi terhadap masalah yurisdiksi dalam penegakan hukum. Hal ini, dikarenakan aparat penegak hukum Indonesia semakin mudah mengakses informasi tentang pelarian aset hasil kejahatan ke negara Iran. Oleh karena itu, MLA dapat digunakan untuk proses hukum penyidikan, penuntutan, sampai eksekusi putusan yang berkekuatan hukum tetap. Penyidikan bisa mendapatkan keterangan saksi, mencari keberadaan seseorang, mengetahui apakah ada aset berupa aset bergerak, rumah, tanah dan yang lain bisa menggunakan MLA tersebut.

Dalam MLA disebutkan Indonesia dapat meminta bantuan Iran untuk melakukan upaya paksa terhadap pelaku kejahatan seperti penggeledahan, pemblokiran rekening, atau membuka rekening bank terduga. Untuk upaya non paksa lainnya, Indonesia juga dapat meminta data daftar perusahaan yang diduga terkait dengan pencucian uang. Namun perlu dicatat kerjasama ini mencakup ekstradisi dan hukuman badan terhadap pelaku tindak pidana.

MLA meliputi tindakan membantu menghadirkan saksi; meminta dokumen, rekaman, dan bukti; penanganan benda dan aset untuk tujuan penyitaan atau pengembalian aset; menyediakan informasi berkaitan dengan suatu tindak pidana; mencari keberadaan seseorang dan asetnya; mencari lokasi dan data diri seseorang serta asetnya, termasuk memeriksa situs internet yang berkaitan dengan orang tersebut. Selain itu, melacak, membekukan, menyita hasil dan alat yang digunakan dalam melakukan tindak pidana; meminta dokumen yang berkaitan dengan suatu tindak pidana; melakukan penahanan terhadap seseorang untuk diinterogasi dan konfrontasi (dengan saksi/alat bukti lain); memanggil saksi dan ahli untuk memberikan pernyataan; serta menyediakan bantuan lain sesuai perjanjian yang tidak berlawanan dengan hukum di negara yang diminta bantuan.

Saat ini terdapat sekitar 100 Warga Negara Iran yang berhadapan dengan permasalahan hukum di Indonesia, dimana sebagian besar merupakan kasus narkotika. Terkait isu perlindungan hak asasi manusia, pihak negara Iran berpandangan bahwa terdapat perbedaan mendasar antara pengertian perlindungan HAM berdasarkan ajaran agama Islam dengan pengertian barat sebagaimana tertuang dalam Universal Declaration of Human Rights, International Covenant on Civil and Political Rights. Lebih lanjut, Negara Iran menyampaikan bahwa sebagai negara dengan penduduk mayoritas Islam terbesar di dunia, Republik Indonesia dan Republik Islam Iran perlu mempererat kerjasama tersebut dapat tertuang dalam $M o U$ kerjasama kedua negara (Kementerian Luar Negeri RI, Direktorat Jenderal Protokol dan Konsuler: Laporan perundingan perjanjian ekstradisi dan perjanjian MLARI-Iran Tehran, 24-25 Februari 2016).

Sedangkan untuk jumlah wisatawan Negara Iran yang berwisata ke luar negeri berjumlah 10 (sepuluh) juta orang per tahun. Namun demikian, jumlah kunjungan warga Negara Iran ke Indonesia, berdasarkan data Direktorat Jenderal Imigrasi, Kementerian Hukum dan Hak Asasi Manusia baru mencapai angka 9 (Sembilan) ribu orang dalam periode Januari s.d. November 2016 (Kementerian Luar Negeri RI, Direktorat Jenderal Protokol dan Konsuler: Laporan Pertemuan Konsultan Bilateral Kekonsuleran ke-3 antara Pemerintah Indonesia dengan Pemerintah Iran di Bandung 4-6 Desember 2016).

Menurut Data Direktorat Jenderal Pemasyarakatan, Jumlah Narapidana dan Tahanan Warga Negara Iran berdasarkan jenis kejahatan berjumlah 91 (Sembilan puluh satu) warga Negara Iran yang bermasalah dengan hukum, sebagaimana table jumlah narapidana dan tahanan warga negara Iran berdasarkan jenis kejahatan. 
Tabel:Jumlah Narapidana dan Tahanan

Warga Negara Iran Berdasarkan Jenis Kejahatan

\begin{tabular}{|l|l|c|c|c|c|c|}
\hline \multirow{2}{*}{ No. } & \multirow{2}{*}{ Jenis Kejahatan } & \multicolumn{2}{|c|}{ Narapidana } & \multicolumn{2}{|c|}{ Tahanan } & \multirow{2}{*}{ Total } \\
\cline { 3 - 6 } & & Laki-laki & Perempuan & Laki-laki & Perempuan & \\
\hline 1 & Keimigrasian & 4 & - & - & - & 4 \\
\hline 2 & Narkotika & 67 & 9 & 3 & - & 79 \\
\hline 3 & Psikotropika & 1 & - & - & - & 1 \\
\hline 4 & Kosong/Tidak Diisi & 5 & - & 2 & - & 7 \\
\hline \multicolumn{2}{|l}{ Jumlah } & 77 & 9 & 5 & 0 & 91 \\
\hline
\end{tabular}

Sumber: Dirjen Pemasyarakatan tanggal 30 Maret 2017

Perkembangan hubungan diplomatik antara Indonesia dan Iran selain meningkatkan hubungan persahabatan dan hubungan dagang, juga meningkatnya ilmu pengetahuan dan teknologi khususnya di bidang transportasi, komunikasi, dan informasi. Selain hubungan tersebut mempunyai dampak positif tetapi tidak menutup kemungkinan adanya dampak negatif, yaitu timbulnya tindak pidana yang tidak lagi mengenal batas yurisdiksi suatu Negara seperti hal kasus hukum warga negara Iran begitu juga warga negara Indonesia yang terlibat hukum di negara Iran, sehingga penanggulangan dan pemberantasannya memerlukan kerja sama antar negara yang efektif bersifat bilateral.

MLA pada dasarnya merupakan suatu bentuk perjanjian timbal balik dalam masalah pidana. Prinsip MLA ini ialah dengan asas resiprokal (asas timbal balik) yaitu masing-masing negara memberikan bantuan kerja sama dalam penyerahan pelaku kejahatan transnasional atas dasar permintaan.Urgensi perjanjian MLA kedua negara ini berdasarkan norma hukum internasional, sebagai berikut:

\section{Kedaulatan dan Globalisasi}

Berdasarkan konsep hukum internasional, kedaulatan memiliki tiga aspek terkait kedaulatannya: (i) Aspek ekstern kedaulatan, yaitu bahwa setiap negara memiliki hak untuk membangun hubungan dengan berbagai negara maupun kelompok lain tanpa tekanan maupun pengaruh dari negara lain. (ii) Aspek intern kedaulatan, yaitu bahwa terdapat hak eksklusif negara untuk menentukan bagaimana pengaturan kelembagaan dalam negeri, termasuk mekanisme pembuatan legislasi serta pengaturan mengenai penegakannya.(iii) Aspek teritorial kedaulatan, yaitu bahwa setiap negara memiliki kekuasaan penuh dan eksklusif atas individu-individu dan benda-benda yang terdapat di wilayah negara tersebut (Mauna, 2000:24).

Sehubungan dengan kedaulatan yang ada pada setiap negara, maka sebagaimana juga terkandung dalam Konvensi Montevideo Tahun 1933 tentang Hak dan Kewajiban Negara, bahwa salah satu unsur konstitutif negara adalah terdapatnya kapasitas untuk menjalin hubungan dengan negara lain. Atas dasar adanya kedaulatan setiap negara inilah maka dalam konteks tindak pidana antar negara diperlukan adanya perjanjian bantuan timbal balik dalam masalah pidana. Bahwa berdasarkan adanya kedaulatan, maka setiap negara adalah setara dan secara ideal tidak terjadi superioritas terutama dalam hal yurisdiksi hukum nasional.

Hukum pidana masing-masing negara merupakan bagian dari aspek intern kedaulatan yaitu bahwa pengembangan hukum materiil maupun formil merupakan hak eksklusif setiap negara berdasarkan mekanisme legislasi masingmasing negara. Berdasarkan aspek teritorial kedaulatan pula maka tercermin adanya kesetaraan dalam hal yurisdiksi teritorial hukum pidana.

Kedaulatan masing-masing negara ini kemudian terbentur dengan perkembangan tindak pidana yang berkembang menjadi tindak pidana antar negara.Menghadapi tindak pidana antar negara membuat kedaulatan menjadi suatu tantangan yang harus dijawab secara lintas batas. Sebagaimana landasan pemikiran yang dikemukakan oleh pemerintah Republik Indonesia melalui Menteri Hukum dan HAM terkait pentingnya pembentukan UndangUndang Bantuan Timbal Balik dalam Masalah Pidana sebagai berikut: (Cahyono, 2009:36) (i) Perkembangan ilmu pengetahuan dan teknologi yang cukup pesat dan semakin canggih dewasa ini khususnya bidang transportasi, komunikasi, dan informasi. Hal ini menyebabkan Indonesia 
semakin tanpa batas.Perpindahan orang dan barang antarnegara berlangsung dengan cepat dan mudah. Orang dapat melakukan tindak pidana tertentu tanpa harus berada di negara tempat kejahatan itu dilakukan.Kejahatan bisa dilakukan tanpa dibatasi waktu dan tempat. (ii) Kemajuan ilmu pengetahuan dan teknologi dipakai untuk lolos dari jerat pidana atau tuntutan hukum. Tindakan itu mempersulit penyidikan, pemeriksaan di muka persidangan dan pelaksanaan putusan pengadilan. Hal ini dapat mengakibatkan permasalahan hukum antarnegara, sehingga perlu upaya penanggulangan dan pembahasan melalui kerjasama dan harmonisasi kebijakan dengan negara lain. (iii) Untuk meletakkan dasar hukum yang kuat guna mengatur bantuan timbal balik dalam masalah pidana dengan undang-undang sebagai pedoman bagi pemerintah dalam membuat perjanjian sejenis dengan negara lain.(iv) Merupakan realisasi persyaratan negara yang ingin keluar dari daftar hitam negara pencuci uang. Hal ini dikarenakan Indonesia pernah masuk daftar hitam dan dalam pengawasan khusus Financial Action Task Force on Money Laundering (FATF).

Globalisasi sebagai suatu perubahan sosial membawa konsekuensi perubahan cepat pada sistem nilai.Perubahan pada sistem nilai tersebut pada gilirannya menuntut adanya penyesuaian pada tatanan penegakan hukum. Perubahan sosial yang tidak dapat terelakkan lagi dalam fora internasional adalah terjadinya globalisasi. Globalisasi menuntut adanya penyesuaian pada seluruh aspek penegakan hukum mulai dari penyesuaian pada struktur hubungan hukum (legal structure), substansi-substansi baru pengaturan hukum (legal substance), dan budaya hukum (legal culture). Kegagalan dalam menyikapi perubahan tersebut (globalisasi) dapat menimbulkan ketidakpastian hukum, penegakan hukum yang jauh dari ideal, pelanggaran hak asasi manusia, serta ketidak berpihakan hukum pada masyarakat. Melalui globalisasi, kejahatan dapat berkembang secara lintas batas negara yang meliputi kejahatan korupsi, perdagangan orang, perdagangan senjata, perdagangan narkotika, Letter of Credit fiktif, praktek pencucian uang, yang semuanya tidak lagi dibatasi oleh yurisdiksi negara.

\section{Kejahatan Antarnegara Terorganisasi}

Kejahatan antar negara terorganisasi berkembang melalui cara-cara yang dikelola menyerupai bisnis-bisnis legal yang memanfaatkan globalisasi. Secara historis, pada era 1980an terdapat hubungan yang kompleks antara produsen narkotika, penyelundupan senjata, dan gerakan-gerakan radikal dan militansi terutama di wilayah Asia Selatan yang menyebabkan wilayah tersebut menjadi wilayah yang tidak stabil secara geopolitik (UNODC Official Wbesite, The Threatof Transnational Organized Crime, http:// www.unodc.org/documents/data-and-analysis/ tocta/1.The-threat-trans-national organizedcrime.pdf, ditelusuri 5 April 2017).

Manifestasi kejahatan antar negara terorganisasi dapat didefinisikan sebagai berikut: (i) lintas batas, baik yang dilakukan oleh orang (pelaku kejahatan, buronan, atau mereka yang sedang melakukan kejahatan, atau korban dalam kasus penyelundupan maupun perdagangan manusia; atau oleh benda (senjata api, seperti saat teroris memasukkan senjata ke dalam pesawat sebelum lepas landas, uang yang akan digunakan dalam kejahatan pencucian uang, benda-benda yang digunakan dalam kejahatan seperti obatobatan terlarang; atau oleh niatan kriminal (seperti penipuan melalui komputer, ketika perintah yang dikeluarkan di negara dan ditransmisikan di negara B). (ii) pengakuan internasional terhadap sebuah bentuk kejahatan. Pada tataran nasional, sesuai dengan prinsip nullum crimen, nulla poena sine lege, sebuah tindakan antisosial baru bisa dianggap sebagai tindak pidana apabila ada aturan hukum tertulis yang mengaturnya, pada tataran internasional, sebuah tindakan bisa dianggap tindak pidana bila dianggap demikian oleh minimal dua negara. Pengakuan ini bisa berasal dari konvensi internasional, perjanjian ekstradisi, atau adanya kesamaan dalam hukum nasionalnya.

Perkembangan variasi dan cakupan kejahatan antarnegara merupakan konsekuensi dari terjadinya globalisasi.Adanya globalisasi membawa pula globalisasi kejahatan yang berkembang menjadi tindak pidana dengan karakter internasional.

\section{Tantangan Prosedural}

Indikasi-indikasi terjadinya ekskalasi tindak pidana antarnegara terlihat pada berbagai respon internasional terhadap tindak pidana antarnegara. Perkembangan perjanjian-perjanjian multilateral untuk mengatasi kejahatan transnasional, khususnya perdagangan obat-obatan terlarang telah ada sejak lama. Peningkatan skala dan cakupan kejahatan transnasional juga berkembang hingga munculnya United Nations Convention 
Against Transnational Organized Crime yang mulai berlaku pada tahun 2003. Lahirnya konvensi ini merupakan indikasi bahwa kejahatan antar negara memiliki dampak yang meluas sehingga memerlukan respon multilateral.

Tantangan prosedural yang muncul pada konteks kejahatan antarnegara adalah dalam hal bagaimana setiap negara dapat merespon kejahatan antarnegara tanpa harus berkompromi dengan seluruh aspek kedaulatannya.Penyesuaian terhadap legal structure, legal substance, dan legal culture tidak dapat lagi dilakukan secara eksklusif. Aspek ekstern kedaulatan negara harus mendapat porsi yang cukup untuk menjamin harmonisasi kebijakan antarnegara dalam menghadapi kejahatan antarnegara.

Pada kajian ilmiah, kontek kejahatan antarnegara berkembang dalam diskusi hukum pidana internasional. Schwarzenberger menguraikan enam definisi hukum pidana internasional, namun dari enam definisi tersebut, terdapat dua definisi yang terkait erat dengan pemanfaat perjanjian internasional dalam menghadapi tindak pidana antarnegara.Pertama adalah hukum pidana internasional dalam arti lingkup teritorial hukum pidana nasional.Kedua adalah hukum pidana internasional dalam arti kerjasama internasional dalam mekanisme administrasi peradilan pidana nasional (Romli Asasmita, 2003:21).

Pengertian yang pertama mendukung pandangan bahwa penerapan yurisdiksi hukum pidana nasional pada luar wilayah teritorial dapat menimbulkan konflik yurisdiksi.Oleh karena itu penerapan hukum pidana nasional pada kejahatan dengan karakteristik lintas negara diserahkan kepada masing-masing sistem hukum nasional. Pengertian yang kedua dapat dikatakan sebagai konsekuensi dari pengertian yang kedua.Bahwa apabila masing-masing negara masih mengakui serta masih ingin diakui yurisdiksi hukum pidana secara teritorial, maka penanggulangan semua kejahatan yang berdimensi antarnegara tidak mungkin dapat dilakukan tanpa adanya bantuan atau kerjasama antar negara satu dengan yang lainnya, baik secara bilateral maupun multilateral (Atmasasmita, 2006:21).

Salah satu bentuk kerjasama yang dikembangkan adalah perjanjian ekstradisi. Penggunaan perjanjian ekstradisi memiliki tantangan tersendiri pada abad ke-18 karena masih banyak negara yang belum merdeka, sehingga ekstradisi mendapat bias mengenai lawan politik. Pada abad 19 dan 20, kendala perjanjian ekstradisi adalah pada pengadaan alat bukti serta potensi terjadinya pengaruh pada hubungan diplomatik antara kedua negara yang terlibat perjanjian ekstradisi tersebut.

Respon terhadap permasalahan pada perjanjian ekstradisi inilah yang kemudian memunculkan konsep bantuan timbal balik dalam masalah pidana melalaui sebuah perjanjian internasional, baik bilateral maupun multilateral. Bantuan timbal balik dalam masalah pidana merupakan bentuk kerjasama yang dianjurkan dalam United Nations Convention Against Corruption (UNCAC) yang kemudian di tingkat nasional terwujud dalam bentuk Undang-Undang Nomor 1 Tahun 2006 tentang Bantuan Timbal Balik dalam Masalah Pidana (Mutual Legal Assistance).

Undang-undang tersebut meliputi antara lain pengambilan dan pemberian barang bukti, termasuk di dalamnya adalah dokumen, identifikasi lokasi seseorang, pelaksanaan permintaan untuk pencarian bukti, penyitaan, pembekuan aset, penyitaan aset hasil kejahatan, pemblokiran, pengambilan keterangan, membantu penyidikan, serta mengadakan persetujuan dengan saksi. Keseluruhan cakupan tersebut tunduk pada asas-asas perjanjian internasional, terutama asas resiprositas (timbal balik) sehingga masingmasing memiliki keuntungan yang secara normatif sama.

Indonesia sebagai negara ekonomi berkembang yang secara geografis sangat luas dengan jumlah penduduk yang banyak dan tersebar di berbagai daerah masih memerlukan lebih banyak perjanjian bantuan timbal balik dalam masalah pidana dengan negara lain dengan berbagai varian kerjasama yang kontekstual, misalnya dengan penggunaan klausula pembagian hasil aset rampasan (sharing forfeited asset) dalam rangka menunjang kinerja yang lebih terukur sesuai besarnya kontribusi Indonesia maupun negara lain.

Perjanjian Bantuan Timbal Balik dalam masalah pidana antara Republik Indonesia dan Republik Islam Iran di berbagai sektor telah menuntut agar Indonesia dan Iran membuat suatu pengaturan dalam praktek pelaksanaan penegak hukum lintas batas dan yuridiksi kedua negara. 
Dengan meningkatnya hubungan kerjasama tersebut, yang tentunya diiringi dengan persoalanpersoalan terkait hukum yang terjadi dalam prosesnya. Sebelumnya, rencana pembentukan perjanjian bantuan timbal balik antara Republik Indonesia dan Republik Islam Iran telah disepakati oleh Kementerian Luar Negeri sebagai focal point perjanjian tersebut. Kementerian Hukum dan HAM sebagai otoritas pusat menyambut baik rencana tersebut dan mendukung Kementerian Luar Negeri dalam membentuk perjanjian antara Pemerintah Republik Indonesia dan Pemerintah Republik Islam Iran.

Hubungan Perjanjian Republik Indonesia dan Republik Islam Iran (kemudian disebut IndonesiaIran) didasarkan atas: (i) masalah ekonomi; (ii) Meningkatnya lalu lintas perjalanan orang; (iii) Anggota UNCAC; dan (iv) Terdapat warga Negara Indonesia-Iran yang menjadi terpidana di masingmasing Negara.

Di samping itu Republik Indonesia dan Republik Islam Iran bertekad untuk memerangi terorisme dan nakotika, sehingga Republik Indonesia dan Republik Islam Iran berkeinginan untuk:(i) memperluas jejaring terkait penguatan hukum internasional; (ii) menunjukkan bahwa Negara Indonesia mempunyai komitmen dalam hal perjanjian MLA; (iii) Narkoba merupakan hal yang menjadi perhatian oleh Negara Iran dalam pemberantasan permasalahan perdagangan gelap narkoba; dan (iv) MLA dianggap sangat penting dalam masalah formil hukum.

Hal lain yang lebih menarik adalah dengan adanya permasalahan hukum Republik Indonesia dan Republik Islam Iran yang bisa diselesaikan dengan baik antar Negara serta didasari oleh hubungan yang baik antara kedua Negara tersebut, oleh sebab itu Republik Indonesia dan Republik Islam Iran berkeinginan untuk meningkatkan kerja sama yang erat dalam bidang penyidikan, penuntutan dan persidangan, termasuk pula penelusuran, pemblokiran, penyitaan, atau perampasan hasil-hasil dan alat untuk melakukan tindak pidana, melalui bantuan hukum timbal balik dalam masalah pidana.

Iran sebagai salah satu negara pertama di Asia Barat yang dianggap sebagai negara yang cukup vokal, selain itu juga Iran sebagai pintu masuk pertama di negara asia bagian barat. Dengan adanya kerjasama dengan Indonesia-Iran ini diharapkan dapat mempengaruhi negara-negara teluk lainnya untuk mengadakan kerjasama timbal balik dengan negara Indonesia.Maka, dapat dilihat dari perjanjian bantuan timbal balik masalah pidana tersebut, lingkup kerjasama dalam MLA setidak-tidaknya meliputi beberapa hal penting, yakni: (i) mengidentifikasi dan mencari orang; (ii) mendapatkan pernyataan, dokumen dan alat bukti lainnya; (iii) mengupayakan kehadiran orang untuk memberikan keterangan; (iv) menyampaikan surat; (v) melaksanakan permintan penggeledahan; dan (vi) pembekuan, penyitaan dan perampasan asset hasil tindak pidana.

Dalam menetapkan mekanisme pelaksanaan bantuan hukum timbal balik pidana tersebut, maka dibentuklah perjanjian Republik Indonesia dan Republik Islam Iran yang akan merumuskan mekanisme bantuan hukum timbal balik serta penetapan pihak yang berwenang yang memiliki otoritas terkait dengan perngajuan permintaan serta bantuan untuk mengidentifikasi baik pelaku kejahatan maupun barang bukti ataupun bantuan untuk mengupayakan kehadiran orang. Secara umum, biasanya mekanisme hubungan dalam bantuan hukum timbal balik akan dilakukan oleh suatu Central Authority ataupun Pejabat Pemegang Otoritas yang berperan sebagai koordinator dalam pengajuan permintaan MLA.

Oleh karena itu, kejahatan transnasional adalah kejahatan lintas negara (transnational crimes) dewasa ini dipandang sebagai salah satu ancaman serius terhadap keamanan global yang dituntut di bawah yurisdiksi hukum domestik/ nasional, tidak berada di bawah yurisdiksi peradilan internasional karena salah satu unsur dari transnasional adalah adanya lintas batas negara, maka diperlukan kerjasama antar negara untuk membantu proses penegakan hukum (Effendi, 2015).

\section{Substansi Perjanjian Bantuan Timbal Balik dalam Masalah Pidana Antara Republik Indonesia dan Republik Islam Iran}

Perundingan Perjanjian Bantuan Timbal Balik Dalam Masalah Pidana Antara Republik Indonesia dan Republik Islam Iran terdapat beberapa isu utama yang mengemuka saat pembahasan adalah terkait ruang lingkup bantuan, pengecualian perjanjian, otoritas pusat dan tata cara komunikasi. Pembahasan terkait isu tersebut menghasilkan suatu kesepakatan, yaitu: 


\section{Tentang Ruang Lingkup Bantuan}

Pada pembahasan tentang Ruang Lingkup Bantuan, bahwa Para Pihak, Antara Republik Indonesia dan Republik Islam Iran, menyepakati untuk penambahan 2 (dua) poin dalam paragraph 3 yaitu: "c) requesting expert advice" dan " $h$ ) recognition and enforcement of judicial decisions".

Adapun hasilnya bahwa: Para Pihak harus, sesuai dengan ketentuan-ketentuan dalam Perjanjian ini dan hukum nasionalnya, atas dasar saling menghormati kedaulatan, kesetaraan, dan keuntungan bersama, saling memberikan seluasluasnya bantuan timbal balik dalam masalah pidana.

Untuk tujuan Perjanjian ini, bantuan timbal balik dalam masalah pidana berarti setiap bantuan yang diberikan oleh Pihak Diminta berkaitan dengan penyidikan, penuntutan, persidangan, atau proses hukum lainnya yang berhubungan dengan tindak pidana, yang pada saat permintaan bantuan diajukan, berada di dalam yurisdiksi Pihak Peminta.

Bantuan timbal balik dapat terdiri atas: (i) pencarian dan pengidentifikasian orang dan barang; (ii) pemeriksaan benda dan tempat; (iii) permintaan bantuan ahli; (iv) penyampaian dokumen, termasuk dokumen untuk mengupayakan kehadiran orang; (v)penyediaan informasi, dokumen, catatan, dan barang bukti; (vi) penyediaan dokumen asli atau salinan resmi dari dokumen yang berkaitan catatan, dan barang bukti; (vii) penyediaan benda, termasuk peminjaman barang bukti; (viii) pengakuan dan pelaksanaan keputusan pengadilan; (ix) penggeledahan dan penyitaan; (x) pengambilan alat bukti dan pemerolehan keterangan; (xi) pengupayaan agar orang yang ditahan dapat memberikan kesaksian atau membantu penyidikan, penuntutan, persidangan, atau tindakan hukum lainnya di Pihak Peminta; (xii) pengupayaan kehadiran saksi atau pengupayaan bantuan seseorang dalam penyidikan, (xiii) pengupayaan untuk menelusuri, memblokir, membekukan, menyita, merampas, serta mengembalikan hasil dan/atau alat untuk melakukan tindak pidana; dan (xiv)setiap bentuk bantuan lain yang tidak dilarang berdasarkan hukum Pihak Diminta.

Perjanjian ini berlaku pula untuk setiap permintaan bantuan timbal balik yang terkait dengan perbuatan ataupun pembiaran tindak pidana yang dilakukan sebelum berlakunya Perjanjian ini. Bantuan juga dapat diberikan dalam kaitan dengan penyidikan, penuntutan, persidangan, atau proses hukum terkait tindak pidana perpajakan, bea cukai, dan pengawasan valuta asing atau setiap masalah pendapatan lainnya. Ketentuan dalam Perjanjian ini tidak boleh memberikan hak apapun kepada perseorangan untuk memperoleh, menolak, atau mengesampingkan bukti, atau menghalangi pelaksanaan permintaan bantuan dimaksud.

\section{Hal yang Dikecualikan dalam Perjanjian}

Pada pembahasan tentang Pengecualian, data yang ada pada informan menyatakan, bahwa Pihak Iran mengusulkan untuk menghapus Pasal 2 Paragraf 1 dengan alasan bahwa akan menutup kemungkinan pengembangan kerjasama hukum dikemudian hari khususnya terkait Transfer of Sentenced dan Transfer of Proceedings. Disamping itu, Paragraf 1 ini juga menegasikan klausul MLA sebagaimana yang diatur dalam Pasal 17 draf perjanjian Ekstradisi. Kedua belah pihak menyepakati tetap mempertahankan Pasal 2 Paragraf 1 dengan penambahan klausul sebagi berikut: "Without prejudice to the conclusion of specific treatiesor arrangement, this treaty shall not apply to:...".

Adapun hasilnya bahwa: tanpa mengesampingkan pembentukan dari perjanjian atau pengaturan tertentu, Perjanjian ini tidak berlaku terhadap: (i) penangkapan atau penahanan seseorang untuk tujuan ekstradisi atas orang tersebut; (ii) pemindahan terpidana untuk menjalani hukuman; dan (iii) pemindahan proses hukum dalam masalah pidana. Tidak ada sesuatupun dalam Perjanjian ini memberikan hak kepada salah satu Pihak untuk menerapkan jurisdiksi dan pelaksanaan fungsi di wilayah Pihak lain yang dimilikinya secara eksklusif untuk pihak berwenang dari Pihak lain dalam hukum nasionalnya.

\section{Fungsi Central Authority dalam Perjanjian}

Dalam pembahasan tentang Otoritas Pusat, data yang ada pada informan menyatakan, bahwa kedua belah pihak menyepakati untuk mengganti judul pasal menjadi "Central Authorities and Manner of Communication. ’'Disepakati pula oleh kedua belah pihak bahwa Central Authority (CA) untuk pelaksanaan perjanjian MLA ini adalah Kementerian Hukum dan HAM (Indonesia) dan Kementerian Kehakiman (Iran).Terkait mekanisme penyampaian dan penerimaan permintaan MLA, Pihak Indonesia dapat menerima posisi tersebut. 
Lebih lanjut kedua belah pihak menyepakati jika terjadi perubahan CA diantara Para Pihak, maka tidak perlu dilakukan amandemen perjanjian namun cukup dengan pemberitahuan melalui saluran diplomatik.

Adapun hasilnya bahwa: (i) untuk tujuan Perjanjian ini, Otoritas Pusat yang ditunjuk oleh Para Pihak saling berkomunikasi satu dengan yang lain mengenai hal-hal yang termasuk dalam ruang lingkup Perjanjian ini melalui saluran diplomatik; (ii) otoritas Pusat yang terdapat dalam Ayat 1 dari Pasal ini adalah Kementerian Hukum dan HakAsasi Manusia Republik Indonesia dan Kementerian Kehakiman Republik Islam Iran; dan (iii) apabila salah satu Pihak mengganti Otoritas Pusat yang ditunjuk, Pihak tersebut memberitahukan kepada Pihak lainnya atas perubahan tersebut melalui saluran diplomatik.

\section{Isi Permintaan dalam Perjanjian}

Data yang ada pada informan menyatakan, bahwa perihal: "Isi Permintaan Dalam Perjanjian" substansinya sama dengan substansi sebagaimana disepakati dalam: "Angka 6. Pelaksanaan Permohonan Bantuan" tersebut di bawah adalah:

\section{a. Syarat Menolak Permintaan Bantuan dari Negara Peminta}

Menurut informan, bahwa asas bantuan hukum timbal balik terdiri dari tiga kategori, yaitu diterima atau dikabulkan, ditolak, atau dapat ditolak.Pertama, kategori BHTP diterima, adalah: (i) dilakukan Perjanjian bilateral/ multilateral; (ii) hubungan baik/Resiprositas; (iii) adanya double criminality. Kedua, kategori BHTB ditolak, yaitu: tindak pidana politik; tindak pidana hukum militer; tindak pidana yang pelakunya telah dibebaskan, diberi grasi, atau telah selesai menjalani pemidanaan; tindak pidana yang jika dilakukan di Indonesia tidak dapat dituntut; alasan suku, jenis kelamin, agama, kewarganegaraan, atau pandangan politik; merugikan kedaulatan, keamanan, kepentingan, dan hukum nasional; tidak digunakan untuk penanganan perkara yang dimintakan; tidak ada jaminan pengembalian barang bukti yang diperoleh berdasarkan bantuan apabila diminta. Ketiga, kategori BHTB dapat ditolak, yaitu: (i) tindak pidana yang jika dilakukan dalam wilayah Indonesia, bukan merupakan tindak pidana; (ii) tindak pidana yang jika dilakukan di luar wilayah Indonesia, bukan merupakan tindak pidana; (iii) tindak pidana yang terhadap orang tersebut diancam dengan pidana mati; atau (iv) merugikan suatu penyidikan, penuntutan, dan pemeriksaan di sidang pengadilan di Indonesia, membahayakan keselamatan orang, atau membebani kekayaan negara.

Dalam Perjanjian Timbal Balik dalam Masalah Antara Republik Indonesia dan Republik Islam Iran, menyatakan, bahwa:

1) Bantuan tidak dikabulkan apabila: (i) menurut Pihak Diminta, pelaksanaan permintaan dapat mengganggu kedaulatan, keamanan, ketertiban umum, dan kepentingan umum; (ii) permintaan terkait dengan tindak pidana yang yang pada akhirnya terdakwa dinyatakan tidak bersalah atau diampuni; (iii) permintaan terkait dengan penuntutan atas seseorang sehubungan dengan tindak pidana yang telah diputus dan berkekuatan hukum tetap; (iv) pihak diminta memiliki alasan kuat untuk meyakini bahwa permintaan bantuan timbal balik diajukan dengan tujuan untuk menuntut seseorang berdasarkan ras, agama, kewarganegaraan, suku, pandangan politik, atau orang tersebut dapat, berdasarkan alasan-alasan dimaksud, diperlakukan tidak adil dalam proses peradilannya; (v) pihak peminta tidak dapat memberikan jaminan bahwa bantuan yang dimintakan tidak dapat dipergunakan untuk tujuan selain yang tercantum dalam permintaan tanpa persetujuan sebelumnya dari pihak diminta; (vi) pihak peminta tidak dapat memberikan jaminan untuk mengembalikan bukti-bukti yang telah diperoleh berdasarkan permintaan bantuan hukum sesuai perjanjian ini; (vii) permintaan berhubungan dengan penyidikan, penuntutan atau pelaksanaan hukuman terhadap seseorang atas perbuatan atau pembiaran; (viii) permintaan berhubungan dengan penuntutan atas seseorang untuk tindak pidana yang orang tersebut tidak dapat dituntut dengan alasan kedaluwarsa apabila tindak pidana dilakukan dalam yurisdiksi pihak diminta; (ix) permintaan berkaitan dengan tindak pidana yang hanya diatur dalam hukum militer, dan bukan merupakan tindak pidana dalam hukum pidana umum; dan (x) permintaan berkaitan dengan tindak pidana yang bersifat politik;

2) Tindak pidana berikut tidak termasuk sebagai tindak pidana yang bersifat politik, yaitu: 
(i) tindak pidana terhadap nyawa atau diri Kepala Negara atau Kepala Pemerintahan atau keluarga inti mereka; (ii) tindak pidana berdasarkan konvensi internasional dalam hal Para Pihak memiliki kewajiban dengan menjadi negara pihak dalam konvensi tersebut, untuk memberikan bantuan timbal balik dalam masalah pidana; (iii) tindak pidana terkait terorisme; dan (iv) percobaan atau permufakatan jahat untuk melakukan setiap tindak pidana sebagaimana tersebut di atas atau turut serta dalam pembantuan kepada seseorang yang melakukan atau mencoba untuk melakukan tindak pidana tersebut;

3) Permintaan bantuan dapat tidak dikabulkan apabila: (i) pemberian bantuan dimaksud dapat, atau mungkin dapat mengancam keselamatan siapapun, walaupun orang tersebut berada di dalam atau di luar wilayah Pihak Diminta; dan (ii) permintaan berkaitan dengan penyidikan, penuntutan ataupun penjatuhan hukuman atas seseorang yang berkenaan dengan suatu alasan yang dapat digunakan sebagai dasar penolakan yang diatur dalam hukum nasional Pihak Diminta;

4) Bantuan tidak dapat ditolak hanya dengan alasan kerahasiaan bank atau lembaga keuangan sejenis atau tindak pidana tersebut juga dinilai terkait dengan masalah fiskal.

\section{b. Pelaksanaan Permohonan Bantuan}

Dalam pembahasan mengenai Pelaksanaan Permintaan, data yang ada pada informan menyatakan, bahwa kedua belah pihak menyepakati bahwa setiap permintaan MLA harus diajukan dalam Bahasa negara peminta dengan melampirkan terjemahannya dalam negara diminta atau Bahasa Inggris, adapun hasilnya adalah:

1) Dalam setiap perkara permintaan bantuan harus mencantumkan: (i) nama pihak yang berwenang melakukan penyidikan, penuntutan atau proses hukum lainnya yang berkaitan dengan permintaan tersebut; (ii) tujuan dari permintaan dan jenis bantuan yang dimintakan; (iii) uraian tentang sifat masalah pidana dan status terkini, serta pernyataan yang menjelaskan rangkuman fakta-fakta dan salinan ketentuan hukum yang dapat dikenakan, termasuk ancaman hukuman maksimal terhadap tindak pidana yang berkaitan dengan permintaan tersebut: (iv) tingkat kerahasiaan yang diperlukan beserta alasannya; (v) batas waktu yang ditentukan untuk memenuhi permintaan tersebut; dan (vi) informasi atau tindakan lain yang mungkin diperlukan berdasarkan hukum nasional Pihak Diminta atau hal lain yang diperlukan untuk melaksanakan permintaan tersebut.

2) Dalam hal-hal berikut, permintaan bantuan harus memuat: (i) dalam hal permintaan untuk pengambilan barang bukti, penggeledahan dan penyitaan, atau penelusuran, pembekuan, penyitaan dan perampasan hasil dan/atau alat untuk melakukan tindak pidana, pernyataan yang memuat informasi atau petunjuk lainnya yang menjelaskan keberadaan hasil dan/atau alat untuk melakukan tindak pidana di yurisdiksi Pihak Diminta; dan (ii) dalam hal menghadirkan orang yang ditahan, keterangan tentang orang atau jabatan orang yang akan bertanggung jawab untuk menahan selama proses pemindahan, lokasi tempat tahanan akan dipindahkan dan kemungkinan tanggal kembalinya tahanan dimaksud.

3) Apabila diperlukan, dan dimungkinkan, permintaan bantuan harus memuat pula: (i) identitas, kewarganegaraan, dan lokasi orang yang menjadi pokok penyidikan, penuntutan atau persidangan pidana; (ii) rincian prosedur khusus atau persyaratan tertentu yang dikehendaki oleh Pihak Peminta untuk dipenuhi beserta alasannya; (iii) dalam hal permintaan untuk mengambil bukti dari seseorang, indikasi tentang apakah diperlukan keterangan di bawah sumpah atau pernyataan yang diakui kebenarannya, dan uraian tentang hal-hal pokok yang terkait dengan bukti atau pernyataan yang diminta; dan (iv) penjelasan mengenai dokumen, catatan, atau barang bukti yang dimintakan.

4) Jika Pihak Diminta menganggap bahwa informasi yang diberikan tidak mencakupi untuk melaksanakan permintaan tersebut, Negara Diminta dapat meminta informasi tambahan agar permintaan dapat dilaksanakan.

5) Permintaan bantuan harus disampaikan secara tertulis. Namun, dalam keadaan mendesak atau apabila diperkenankan oleh Pihak Diminta, permintaan dapat disampaikan dalam bentuk lain, tetapi kemudian harus 
segera ditegaskan kembali secara tertulis; dan

6) Suatu permintaan, setiap dokumen pendukung, dan komunikasi yang dilakukan sesuai dengan Perjanjian ini, harus disampaikan dalam bahasa Pihak Peminta disertai oleh terjemahan dalam bahasa Pihak Diminta atau bahasa lnggris.

\section{Cara Penyampaian Dokumen Bantuan}

Pada pembahasan terkait Penyampaian Dokumen, data yang ada pada informan menyatakan, bahwa Pihak Iran mengusulkan penambahan yang mengatur mengenai upaya maksimal negara diminta dalam penyampaian dokumen atau surat sesuai dengan hukum yang berlaku di negara diminta, adapun hasilnya adalah:

1) Pihak Diminta harus memenuhi permintaan penyampaian dokumen yang dikirimkan kepadanya untuk tujuan penyampaian dokumen tersebut oleh pihak Peminta;

2) Pihak Peminta harus mengirimkan permintaan untuk penyampaian dokumen mengenai tanggapan atau kehadiran di Pihak Peminta dalam waktu yang cukup, sebelum tanggapan atau kehadiran yang telah dijadwalkan;

3) Pihak Diminta harus menyampaikan kepada Pihak Peminta tanda terima penyampaian dokumen. Jika penyampaian dokumen tidak dapat dilaksanakan, Pihak Peminta harus diberitahukan alasan-alasannya;

4) Dalam situasi apabila alamat yang dituju tidak lengkap atau tepat dan/atau orang dituju tidak diketahui di alamat dimaksud, Pihak Diminta harus berupaya sebaik mungkin untuk mendapatkan alamat penerima, sesuai dengan hukum yang berlaku; dan

5) Dalam situasi dokumen tidak dibuat dalam bahasa Pihak Diminta atau tidak disertai terjemahan resmi, dokumen tetap disampaikan jika penerima menyetujui untuk menerima dokumen tersebut.

\section{b. Pengaturan Berbagai Masalah}

1) Penyediaan Informasi, Dokumen, Catatan, dan Benda

Mengenai penggeledahan dan penyitaan, menurut informan bahwa Pihak Diminta, berdasarkan permintaan, menyediakan kepada Pihak Peminta salinan dokumen atau catatan kementerian dan lembaga pemerintahan yang terbuka bagi umum.

Pihak Diminta dapat, berdasarkan permintaan, menyediakan kepada Pihak Peminta setiap informasi, dokumen, catatan, dan benda yang berada dalam penguasaan kementerian atau lembaga pemerintah, tetapi tidak terbuka bagi publik, sepanjang dimungkinkan dan sesuai dengan persyaratan yang sama sebagaimana halhal tersebut dapat tersedia untuk lembaga penegak hukum dan lembaga peradilan. Pihak Diminta dapat menyediakan salinan resmi dokumen atau catatan, kecuali Pihak Peminta secara jelas meminta yang asli.

Berdasarkan permintaan, dokumen, catatan atau benda asli yang telah diberikan kepada Pihak Peminta harus dikembalikan kepada Pihak Diminta sesegera mungkin. Sepanjang tidak dilarang oleh hukum Pihak Diminta, dokumen, catatan, atau benda harus diberikan dalam suatu formulir atau dilengkapi dengan sertifikasi sebagaimana dikehendaki oleh Pihak Peminta agar dokumen, catatan atau benda dimaksud dapat dipergunakan sesuai hukum Pihak Peminta.

\section{2) Penggeledahan dan Penyitaan}

Mengenai penggeledahan dan penyitaan, menurut informan bahwa Pihak Diminta, sepanjang dibenarkan oleh hukumnya, melaksanakan permintaan untuk penggeledahan dan penyitaan berkaitan dengan tindak pidana yang terjadi di Pihak Diminta. Penggeledahan dan penyitaan dilaksanakan oleh Pihak Diminta sepanjang dimungkinkan dan dengan persyaratan yang sama sesuai dengan hukumnya. Pihak yang berwenang dari Pihak Diminta menyediakan informasi yang mungkin diperlukan tersebut oleh Pihak Peminta mengenai, tetapi tidak terbatas pada, setiap hasil penggeledahan, tempat, identitas, keadaan, integritas, dan kesinambungan penguasaan dokumen, catatan atau benda yang disita dan keadaan pada saat penyitaan, serta penyimpanan benda sitaan tersebut selanjutnya.

3) Pengambilan Barang Bukti

Pada pembahasan tentang bantuan mendapatkan alat bukti, data yang ada pada informan menyatakan, bahwa kedua belah pihak menyepakati untuk mengganti kata "to decline" menjadi "to refrain", adapun hasilnya adalah: 
a) Pihak Diminta harus memenuhi permintaan penyampaian dokumen yang dikirimkan kepadanya untuk tujuan penyampaian dokumen tersebut oleh pihak Peminta;

b) Pihak Peminta harus mengirimkan permintaan untuk penyampaian dokumen mengenai tanggapan atau kehadiran di Pihak Peminta dalam waktu yang cukup, sebelum tanggapan atau kehadiran yang telah dijadwalkan;

c) Pihak Diminta harus menyampaikan kepada Pihak Peminta tanda terima penyampaian dokumen. Jika penyampaian dokumen tidak dapat dilaksanakan, Pihak Peminta harus diberitahukan alasan-alasannya;

d) Dalam situasi apabila alamat yang dituju tidak lengkap atau tepat dan/atau orang dituju tidak diketahui di alamat dimaksud, Pihak Diminta harus berupaya sebaik mungkin untuk mendapatkan alamat penerima, sesuai dengan hukum yang berlaku; dan

e) Dalam situasi dokumen tidak dibuat dalam bahasa Pihak Diminta atau tidak disertai terjemahan resmi, dokumen tetap disampaikan jika penerima menyetujui untuk menerima dokumen tersebut.

4) Kehadiran Pihak Diminta Pada Saat Pelaksanaan Permintaan

Pada pembahasan tentang kehadiran dalam eksekusi permintaan, data yang ada pada informan menyatakan, bahwa kedua belah pihak menyepakati untuk menambahkan 1 (satu) paragraph baru sebagai berikut: "2. To the extent that it is not contrary to the domestic laws of the requested party, the requesting party may serve the papers and documents through its diplomatic or consular mission," adapun hasilnya bahwa:

a) Sepanjang dibenarkan oleh hukum nasionalnya, Pihak Diminta dapat mengizinkan kehadiran dari perwakilan dari Pihak Diminta untuk menghadiri pelaksanaan pemenuhan permintaan sesuai dengan tata cara dari Pihak Diminta; dan

b) Sepanjang tidak dilarang oleh hukum dari Pihak Diminta, pejabat berwenang Pihak Peminta dapat menyampaikan berkas dan dokumen melalui perwakilan diplomatik atau konsulernya.

5) Kesediaan Tahanan Untuk Memberikan Bukti Atau Bantuan
Dalam pembahasan mengenai Pelaksanaan Permintaan, data yang ada pada informan menyatakan, bahwa berdasarkan permintaan Pihak Peminta, Pihak Diminta mengundang orang, berdasarkan kesediaannya yang dinyatakan sebelumnya, untuk membantu penyidikan atau hadir sebagai saksi dalam persidangan di Pihak Peminta. Orang tersebut harus diberitahu mengenai perlindungan, fasilitas, dan tunjangan yang akan diberikan.

6) Pemberian Bukti Atau Bantuan Penyidikan di Pihak Peminta

Dalam pembahasan mengenai Pelaksanaan Permintaan, data yang ada pada informan menyatakan, bahwa berdasarkan permintaan Pihak Peminta, Pihak Diminta mengundang orang, berdasarkan kesediaannya yang dinyatakan sebelumnya, untuk membantu penyidikan atau hadir sebagai saksi dalam persidangan di Pihak Peminta. Orang tersebut harus diberitahu mengenai perlindungan, fasilitas, dan tunjangan yang akan diberikan.

7) Tindakan Jaminan Keselamatan Terhadap Seseorang Yang Berada di Pihak Peminta

Dalam pembahasan mengenai Pelaksanaan Permintaan, data yang ada pada informan menyatakan, bahwa sesuai dengan kesepakatan sebagaimana dimaksud dalam "kesediaan tahanan untuk memberikan bukti atau bantuan" dan "pemberian bukti atau bantuan penyidikan di pihak peminta", bahwa seseorang yang berada di Pihak Peminta untuk memenuhi suatu permintaan tidak boleh dituntut, ditahan, atau dikenakan pembatasan kemerdekaannya di Pihak Peminta atas setiap perbuatan atau pembiaran yang terjadi sebelum keberangkatan orang tersebut dari Pihak Diminta, orang tersebut juga tidak boleh diwajibkan untuk memberikan bukti dalam setiap proses hukum selain dari proses hukum yang berkaitan dengan permintaan.

Hal itu tidak berlaku lagi jika seseorang, yang bebas untuk pergi meninggalkan Pihak Peminta, tidak meninggalkan dalam jangka waktu 15 (lima belas) hari setelah pemberitahuan resmi bahwa kehadiran orang tersebut tidak diperlukan lagi atau, setelah meninggalkan, kembali secara sukarela.

Setiap orang yang memberikan persetujuan untuk memberikan bukti berdasarkan kesepakatan sebagaimana dimaksud dalam "kesediaan tahanan 
untuk memberikan bukti atau bantuan" dan "pemberian bukti atau bantuan penyidikan di pihak peminta", tidak boleh dituntut atas dasar kesaksiannya, kecuali untuk sumpah palsu atau penghinaan terhadap pengadilan. Setiap orang yang tidak memberikan persetujuan atau tidak dapat hadir di Pihak Peminta tidak dapat dikenakan upaya paksa apapun di Pihak Diminta.

8) Hasil dan Alat Untuk Melakukan Tindak Pidana

Dalam pembahasan mengenai Pelaksanaan Permintaan, data yang ada pada informan menyatakan, bahwa "hasil tindak pidana" adalah barang apapun yang berasal dari atau diperoleh, secara langsung maupun tidak langsung, melalui perbuatan pidana dan alat untuk melakukan tindak pidana" adalah barang apapun yang digunakan dan bertujuan untuk digunakan dalam perbuatan pidana, atau nilai yang setara dengan barang tersebut.

Pihak Diminta, berdasarkan permintaan, berusaha untuk memastikan apakah terdapat hasil dan/atau alat untuk melakukan tindak pidana yang berada dalam yurisdiksinya dan memberi tahu Pihak Peminta mengenai hasil penelusuran. Pihak Peminta harus pula memberikan informasi yang diperlukan atau bukti lain apapun yang menunjukkan keberadaan hasil dan/atau alat untuk melakukan tindak pidana tersebut di yurisdiksi Pihak Diminta.

Dalam hal hasil dan/atau alat untuk melakukan tindak pidana yang diduga tersebut ditemukan, Pihak Diminta harus mengambil langkah yang dibenarkan oleh hukumnya untuk menggeledah, membekukan, memblokir, dan menyita hasil dan/ atau alat untuk melakukan tindak pidana yang dicurigai tersebut, menunggu keputusan akhir mengenai hasil dan/atau alat untuk melakukan tindak pidana tersebut oleh pengadilan Pihak Peminta.

Pihak Diminta yang menguasai hasil dan/ atau alat untuk melakukan tindak pidana yang dirampas atau disita, untuk melaksanakan putusan Pengadilan Pihak Peminta mengambil tindakan yang diperlukan terhadap hasil dan/ atau alat untuk melakukan tindak pidana tersebut berdasarkan hukumnya Sepanjang dibenarkan oleh hukumnya, Pihak Diminta menyerahkan hasil dan/atau alat untuk melakukan tindak pidana yang telah dirampas atau disita tersebut kepada Pihak Peminta.
Dalam menerapkan Pasal ini, hak pihak ketiga yang beriktikad baik harus dihormati berdasarkan hukum Pihak Diminta. Apabila terdapat gugatan dari pihak ketiga, Pihak Diminta harus mewakili kepentingan Pihak Peminta untuk berupaya mempertahankan hasil dan/atau alat untuk melakukan tindak pidana hingga adanya suatu putusan yang berkekuatan hukum tetap oleh Pengadilan yang berwenang di Pihak Peminta.

\section{e. Masalah Transit Seseorang yang akan Diekstradisi dari Suatu Negara Pihak Ketiga ke Salah Satu Pihak Melalui Pihak Lainnya}

Pada pembahasan tentang Transit, data yang ada pada informan menyatakan, bahwa Para Pihak menyepakati untuk menggunakan klausul Transit yang ada dalam draft perjanjian ekstradisi dengan penyesuaian untuk mengakomodir ketentuan mengenai MLA, adapun hasilnya adalah: (i) Sepanjang diperbolehkan oleh hukum nasionalnya, transit seseorang yang akan diekstradisi dari suatu negara ketiga ke salah satu Pihak melalui wilayah Pihak lainnya akan diizinkan berdasarkan permintaan yang disampaikan melalui saluran Central Authority. Izin transit tidak diperlukan dalam penggunaan transportasi udara dan tidak ada pendaratan yang dijadwalkan di wilayah Pihak yang digunakan sebagai tempat transit; dan

(ii) Apabila terjadi pendaratan tidak terjadwal di wilayah Pihak tersebut, Pihak tersebut dapat mensyaratkan Pihak lainnya untuk melengkapi permintaan transit sebagaimana telah ditetapkan tersebut di atas. Pihak tersebut, sepanjang tidak bertentangan dengan hukum nasionalnya, dapat menahan orang yang akan diekstradisi tersebut untuk jangka waktu 72 (tujuh puluh dua) jam sambil menunggu permintaan transit.

\section{f. Kerahasiaan Informasi dan Batasan Penggunaan Informasi}

Dalam Perjanjian Timbal Balik dalam Masalah Antara Republik Indonesia dan Republik Islam Iran menurut data yang ada pada informan menyatakan, bahwa: Pihak Diminta memastikan untuk: (i) menjaga kerahasiaan informasi atau bukti yang diberikan atau sumber informasi tersebut sesuai dengan permintaan bantuan; (ii) menjaga kerahasiaan isi, dokumen pendukung dan setiap tindakan yang diambil sesuai dengan permintaan bantuan; dan (iii) melindungi informasi atau bukti dari kehilangan, akses tanpa ijin, pengubahan, 
pembocoran, atau penyalahgunaan. Di samping itu apabila permintaan sesuai dengan ketentuan Ayat 1 dari Pasal ini tidak dapat dilaksanakan tanpa melanggar persyaratan kerahasiaan, Pihak Diminta harus memberi tahu Pihak Peminta sebelum pelaksanaan permintaan dan Pihak Peminta harus menentukan apakah permintaan tersebut tidak lagi perlu dilaksanakan, seperti:

\section{Pengesahan}

Pada pembahasan masalan Ketentuan Penutup, Para Pihak menyepakati bahwa memberlakukan perjanjian MLA ini adalah 30 hari setelah diterimanya pemberitahuan terakhir bahwa pihak tersebut telah menyelesaikan proses pemberlakuan inrternalnya, adapun hasilnya adalah: (i) Para Pihak harus memberitahukan satu sama lain mengenai selesainya persyaratan domestik masing-masing untuk pemberlakuan Perjanjian ini. Perjanjian ini mulai berlaku pada hari ketiga puluh setelah tanggal diterimanya pemberitahuan pemberlakuan yang paling akhir; (ii) Salah satu Pihak dapat mengakhiri Perjanjian ini sewaktu-waktu memberitahukan secara tertulis kepada Pihak lainnya melalui diplomatik. Pengakhiran ini berlaku setelah 6 (enam) bulan sejak diterimanya pemberitahuan mengenai pengakhiran dimaksud. Pengakhiran Perjanjian tidak akan memengaruhi permintaan ekstradisi yang telah disampaikan sebelum pengakhiran Perjanjian ini. dengan saluran.

2. Biaya

Perjanjian Bantuan Timbal Balik dalam MasalahPidanaDalamPerjanjianTimbalBalik dalam Masalah Antara Republik Indonesia dan Republik Islam Iran menurut data yang ada pada informan menyatakan, bahwa: Pihak Diminta menanggung biaya untuk memenuhi permintaan bantuan, kecuali biaya yang harus ditanggung oleh Pihak Peminta yaitu: (i) biaya yang berhubungan dengan pengangkutan orang ke atau dari wilayah Pihak Diminta atas permintaan dari Pihak Peminta berdasarkan permintaan menurut Pasal 12 dan 13 Perjanjian ini; (ii) biaya dan upah tenaga ahli baik di Pihak Diminta atau di Pihak Peminta; (iii) biaya penerjemahan, penafsiran, dan pentranskripsian; (iv) biaya yang berhubungan dengan pengambilan bukti dari Pihak Diminta ke Pihak Peminta melalui video, satelit, atau sarana teknologi lainnya; dan (v) Jika ternyata pelaksanaan permintaan tersebut membutuhkan biaya yang besar, Para Pihak harus berkonsultasi untuk menentukan dengan syarat dan dalam kondisi apa bantuan dapat diberikan, seperti:

3. Kewajiban Internasional

Dalam PerjanjianTimbal Balik dalam Masalah Antara Republik Indonesia dan Republik Islam Iran menurut data yang ada pada informan menyatakan, bahwa: Perjanjian ini tidak akan memengaruhi hak dan kewajiban Para Pihak mengenai bantuan timbal balik dalam masalah pidana berdasarkan konvensi internasional atau pengaturan lainnya yang dalam hal ini mereka menjadi pihak.

4. Konsultasi

Dalam Perjanjian Timbal Balik dalam Masalah Antara Republik Indonesia dan Republik Islam Iran menurut data yang ada pada informan menyatakan, bahwa: Para Pihak saling berkonsultasi, pada waktu yang disetujui bersama, untuk mendorong pelaksanaan Perjanjian ini dengan cara yang paling efektif. Kedua belah Pihak juga dapat menyepakati langkah praktis yang dipandang perlu untuk memfasilitasi pelaksanaan Perjanjian ini.

5. Penyelesaian Sengketa

Dalam Perjanjian Timbal Balik dalam Masalah Antara Republik Indonesia dan Republik Islam Iran menurut data yang ada pada informan menyatakan, bahwa: Setiap sengketa yang timbul akibat penafsiran atau pelaksanaan Perjanjian ini akan diselesaikan dengan konsultasi antara Para Pihak.

6. Masalah Amandemen

Dalam Perjanjian Timbal Balik dalam Masalah Antara Republik Indonesia dan Republik Islam Iran menurut data yang ada pada informan menyatakan, bahwa: Perjanjian ini dapat diubah setiap saat melalui kesepakatan tertulis Para Pihak. Amandemen dimaksud akan berlaku melalui prosedur yang sama dengan prosedur pemberlakuan Perjanjian ini. 


\section{KESIMPULAN}

Mutual Legal Assistance pada dasarnya merupakan suatu bentuk perjanjian timbal balik dalam masalah pidana. Prinsip MLA ini ialah dengan asas resiprokal (asas timbal balik) yaitu masing-masing negara memberikan bantuan kerja sama dalam penyerahan pelaku kejahatan transnasional atas dasar permintaan.

Akibat perkembangan ilmu pengetahuan dan teknologi khususnya di bidang transportasi, komunikasi, dan informasi telah mengakibatkan hubungan lintas negara seakan-akan tanpa batas sehingga memudahkan mobilisasi orang maupun perpindahan barang dari satu negara ke negara lain dapat dilakukan dengan cepat maka hubungan Republik Indonesia dan Republik Islam Iran meningkat selaras dengan kemajuan sehingga memunculkan dampak positif juga mempunyai dampak negatif yaitu timbulnya tindak pidana yang tidak lagi mengenal batas yurisdiksi suatu negara sehingga penanggulangan dan pemberantasannya memerlukan kerja sama antarnegara yang efektif baik bersifat bilateral maupun multilateral meliputi pengambilan alat/barang bukti atau pernyataan orang, pemberian informasi, dokumen, catatan, dan barang bukti.

Selain itu, hal yang sangat mendasar untuk meratifikasi dalam melakukan perjanjian hubungan timbal balik masalah pidana Indonesia dengan Iran adalah: (i) pengawasan peredaran narkotika, mengingat masuknya narkotika melalui warga Negara Iran cukup tinggi; (ii) meningkatkan eksistensi Indonesia dalam politik luar negeri; dan (iii) membawa dampak kepada negara-negara di Kawasan Timur Tengah untuk menjalin hubungan dengan Indonesia.

\section{SARAN}

Untuk menindaklanjuti Perjanjian ini, Pemerintah diharapkan dapat segera meratifikasi Perjanjian antara Indonesia dan Iran tentang Bantuan Timbal Balik dalam Masalah Pidana sesuai dengan ketentuan hukum nasional yang berlaku, dan perlu mempersiapkan pelaksanaan berbagai komitmen di tingkat nasional sehingga memerlukan peningkatan koordinasi antar instansi terkait dan interaksi dengan para pemangku kepentingan.

Indonesia perlu meningkatkan kapasitas kelembagaan dan profesionalisme sumber daya manusia, seperti dilakukan sinkronisasi antar penegak hukum mengenai kewenangan masing-masing Competent Authoritydalam menangani MLA agar tidak saling menunggu dalam penanganannya. Hal ini dijabarkan lebih lanjut dalam peraturan pelaksanaan mengenai kewenangan masing-masing Competent Authority dalam menangani MLA, danmelakukan koordinasi internal masing-masing Competent Authoritydalam menangani MLA, serta perlu penanganan birokrasi Bantuan Timbal Balik Masalah Pidana yang cepatdalam menangani suatu kasus masalah pidana pada masing-masing negara memberikan bantuan kerja sama dalam penyerahan pelaku kejahatan transnasional. 


\section{DAFTAR KEPUSTAKAAN}

\section{Buku}

Badan Pembinaan Hukum Nasional, Analisis dan Evaluasi Hukum Terhadap UU No 1 tahun 2006 tentang Bantuan Timbal Balik dalam Masalah Pidana. Jakarta, 2010.

Mauna, Boer, Hukum Internasional. Alumni, Bandung, 2000.

Cahyono, Perlunya MLA (Mutual Legal Assitence) dalam Proses Penegakan Hukum. Majalah Hukum Varia Peradilan, Vol. 24 No. 283, Juni 2009.

Parthiana, Wayan, I, HukumPerjanjian Internasional

Bagian 2. Mandar Maju, Bandung, 2005.

Harris, E, Jhon, International Cooperation in Fighting Transnational Organized Crime :114th Internationa Special Emphasis on Mutual Legal Assistance and Extradition, Training Course Visiting Experts Papers.

Kementerian Luar Negeri RI, Direktorat Jenderal Protokol dan Konsuler, Laporan Perundingan Perjanjian Ekstradisi Dan Perjanjian MLA RI-Iran Tehran, 24-25 Februari 2016.

Kementerian Luar Negeri RI, Direktorat Jenderal Protokol dan Konsuler, Laporan Pertemuan Konsultan Bilateral Kekonsuleran ke- 3 antara Pemerintah Indonesia dengan Pemerintah Iran di Bandung 4-6 Desember 2016.

Kementerian Luar Negeri RI, Direktorat Jenderal Protokol dan Konsuler, Laporan Perundingan Perjanjian Ekstradisi Dan Perjanjian MLA Ri-Iran Tehran, 24-25 Februari 2016.

Atmasasmita, Romli. Pengantar Hukum Pidana Internasional. Refika Aditama, Bandung, 2003.

Optional Protocol UN Model Treaty on Mutual Assistance in Criminal Matters (1990), 14 Desember1990.

Cyrer, Robert, Friman, Hakan, et all, An Introduction to International Criminal Law and Procedure, Cambridge University Press, 2010.

Atmasasmit, Romli, Hukum Pidana Internasional. Refika Aditama, Bandung, 2006.
Sunarso, Siswanto, Ekstradisi dan Bantuan Timbal Balik dalam Masalah Pidana (Instrumen Penegakan Hukum Pidana Internasional). Rineka Cipta, Jakarta, 2009.

Soekanto, Soerjono dan Mamudji Sri, Penelitian Hukum Normatif Suatu Tinjauan Singkat, Rajawali Pers. Jakarta, 2006.

The Mutual Assistance in Criminal Matters Act 1987.

Effendi, Tolib, Hukum Pidana Internasional. Pustaka Yustisia, Yogyakarta, 2015

Toolkit to Combat Trafficking in Persons, 2008.

UU No. 1 Tahun 2006 tentang MLA dan Paparan "Peran Kejaksaan dalam Proses MLA", disampaikan dalam rapat "Koordinasi Perencanaan dan Penganggaran Otoritas Pusat dalam rangka Bantuan Timbal Balik, Ruang Rapat SG-5, disampaikan oleh Ibu Mahayu, Sub bagian MLA \& ekstradisi, Biro Hukum dan Hubungan Luar negeri, Kejaksaan Agung Republik Indonesia, Bappenas, 27 Mei 2013.

Hussein, Yunus, Perspektif dan Upaya yang dilakukan dalam Perjanjian Bantuan Timbal Balik Mengenai Tindak Pidana Pencucian Uang (Money Laundering), disampaikan pada "Seminar Tentang Bantuan Timbal Balik dalam Masalah Pidana" diselenggarakan oleh BPHN, Bandung, 29-30 Agustus 2006.

\section{Peraturan Perundang-Undangan}

Undang-Undang Dasar Negara Republik Indonesia Tahun 1945.

Undang-Undang Nomor 37 Tahun 1999 tentang Hubungan Luar Negeri (Lembaran Negara Republik Indonesia Tahun 1999 Nomor 156, Tambahan Lembaran Negara Republik Indonesia Nomor 3882).

Undang-Undang Nomor 24 Tahun 2000 tentang Perjanjian Internasional (Lembaran Negara Republik Indonesia Tahun 2000 Nomor 185, Tambahan Lembaran Negara Republik Indonesia Nomor 4012),

Undang-Undang Nomor 1 Tahun 2006 tentang Bantuan Timbal Balik dalam Masalah Pidana (Lembaran Negara Republik Indonesia Tahun 2006 Nomor 18, Tambahan Lembaran Negara Republik Indonesia Nomor 4607). 


\section{Sumber Lain}

UNODC Official Wbesite, The Threat of Transnational Organized Crime, http://www. unodc.org/ documents/data-and-analysis/ tocta/1.The-threat-transnational-organizedcrime.pdf, ditelusuri 5 April 2017

UNODC Official Wbesite, The Threat of Transnational Organized Crime, http://www. unodc.org/documents/data-and-analysis/ tocta/l.The-threat-transnational-organizedcrime.pdf, ditelusuri 5 April 2017.

Chapter 14: Mutual Legal Assistance and Extradition dalam www. usip.org/files/MC2/ MC2-21-Ch14.pdf, diunduh pada 22 Mei 2017.

International Assistance, http://www.ppsc-sppc. gc.ca/eng/fps-sfp/fpd/ch43.html, diunduh pada 20 Maret 2017.

https://news.detik.com/berita/d-3372675/ indonesia-iran-sepakat-saling-bantu-dibidang-hukum, diunduh pada tanggal 5 April 2017.

https://news.detik.com/berita/d-3372675/ indonesia-iran-sepakat-saling-bantu-dibidang-hukum, diunduh pada tanggal 5 April 2017.

Refusal of Mutual Legal Assistance or Extradition,http://www.unafei.or.jp/ english/ pdf/ PDFrms/no57/57-16.pdf, diunduh pada 1 Maret 2017. 